\title{
DETERMINATION OF MATERNAL ANTIBODY (IGY) CONCENTRATION AS A GENETIC MARKER TO IMPROVE FERTILITY, HATCHABILITY AND LIVABILITY PERCENTAGES IN TWO LOCAL STRAINS OF CHICKENS
}

\author{
G. M. Gebriel ${ }^{(1)}$, A.A. El-Fiky ${ }^{(1)}$, H.R.A. Samak ${ }^{(2)}$, E.M. Abou-Elewa ${ }^{(1)}$ \\ and Basma A.A. El-Mougy ${ }^{(1)}$ \\ (1) Dept. of Poultry and Fish Production, Faculty of Agric., Menoufia Univ., Egypt. \\ (2) Animal Research Institute, Agric., Research Center, Minstry of Agriculture
}

Received: Mar. 20 , 2018

Accepted: Apr. 3, 2018

ABSTRACT: The present study was carried out at the Department of Poultry and Fish Production, Faculty of Agriculture at Shibin El-Kom, Menoufia University. The aim of the present study was to determine the concentrations of maternal antibody (IgY) in blood serum of layers and hatched chicks, in addition to egg yolk of three, control, high and low IgY antibody lines of Sinai and Silver Montazah local strains of chickens as a genetic marker to improve fertility, hatchability and livability percentages.

The results were summarized as follows:

1. Sinai strain had significantly higher IgY antibody concentration than Silver Montazah strain of chickens, being $4.68 \mathrm{vs} 4.22 \mathrm{mg} / \mathrm{ml}$ in hen blood serum, $4.11 \mathrm{vs} 3.46 \mathrm{mg} / \mathrm{ml}$ in egg yolk, 3.09 vs $2.66 \mathrm{mg} / \mathrm{ml}$ in hatched chicks serum and $48.00 \mathrm{vs} 38.41 \mathrm{mg} / \mathrm{egg}$ yolk total, respectively.

2. Highly significant differences $(P \leq 0.01)$ among lines, the high $(L H)$ lines harvested the highest IgY level and control line (CL) occupied intermediate level, whereas the low lines (LL) had the lowest IgY level in both strains of chickens. The means of $\lg Y$ concentrations were 3.74, 6.15 and $2.44 \mathrm{mg} / \mathrm{ml}$ in Silver Montazah strain, where the corresponding values in Sinai strain were $4.63,6.65$ and $2.47 \mathrm{mg} / \mathrm{ml}$ for control, $\mathrm{HL}$ and LL lines, respectively.

3. The high $\lg Y$ antibody lines had significant $(P \leq 0.05)$ higher percentages of fertility than the control and low $\lg Y$ antibody lines. The averages of fertility percentages were 76.97 vs 77.21 for control lines, 85.29 vs 88.19 for high lines and 68.38 vs 68.81 for low lines of Silver Montazah and Sinai strains of chickens, respectively.

4. The means of hatchability percentages of fertile eggs were $72.32 \%$ vs $77.60 \%$ for Silver Montazah and Sinai chickens, respectively. Also, means of hatchability percentages were 89.18 vs $\mathbf{9 1 . 8 9 \%}$ for high lines, 75.11 vs $\mathbf{7 7 . 6 5 \%}$ for control lines and 57.07 vs 61.33\% for low lines of Silver Montazah and Sinai strains of chickens, respectively.

5. Sinai chickens had significantly $(P \leq 0.5)$ higher livability (\%) as compared to Silver Montazah chickens (80.65 vs $75.14 \%$ ) due to the direct action of maternal antibody (IgY) transferred from layers to newly hatched chicks.

6. High IgY lines had significantly $(P \leq 0.5)$ higher percentages of livability at $28 d$. The means of livability (\%) were 75.83 vs 80.91 (\%) for control lines, 87.92 vs 93.49 (\%) for high lines, and 65.29 vs 65.79 (\%) for low lines of Silver Montazah and Sinai strains of chickens, respectively.

7. Since the high IgY antibody improved fertility, hatchability and viability, So that, the IgY can be used as a genetic marker to improve some productive traits in chickens.

Key words: Maternal antibody, productive traits, chickens. 


\section{INTRODUCTION}

1. What is maternal antibody in both birds and mammals?.

In birds, maternal factors are mainly transferred via the egg to the offspring (Grindstaff et al., 2003), hence the time period for the uptake of maternal factors is restricted to a period before, and shortly after hatch. While, in mammals, maternal factors can be transferred via the placenta, in colostrums (the first milk transferred from the mother to her offspring just after birth) and in normal milk during lactation (Glezen 2003 and Lemke et al., 2004).

Among the maternal factors which can be transferred by the mother to her offspring are hormones, antibodies and nutrients (Rubolini et al., 2006 and Biard et al., 2007). In birds, maternal transfer of antibody via egg yolk to offspring has mainly been studied in poultry as means of improving chick survival early in life (Blount et al., 2002 and Biard et al., 2007).

Since, 1996, IgY technology has become the internationally accepted term for describing the production and using of IgG antibody in chickens (Schade, and Hlinak, 1996).

\section{The IgY concentrations in blood serum and egg yolk:}

Three immunoglobulin classes, which are distinguishable in concentration structure, and immunochemical function, are found in birds: $\lg A, \lg M$, and $\lg Y$. The birds $\operatorname{Ig} A$ and $\operatorname{Ig} M$ are similar to mammalian $\lg A$ and $\lg M$ in molecular weight, structure and electrophoretic mobility (Carlander, 2002). But, the molecular weight of the chickens IgY was found by mass spectrometry to be 167and $250 \mathrm{Da}$, while the MW of mammalian IgG is about 160.000 Da (Sun et al., 2001).

Early reports about the concentration of antibody classes in birds indicated that IgY makes up about $75 \%$ of the total immunoglobulin pool. The serum concentration of $\lg \mathrm{Y}, \lg \mathrm{A}$, and $\lg \mathrm{M}$ have been reported to be $5.0,1.25$, and 0.61 $\mathrm{mg} / \mathrm{ml}$, respectively (Lestie and Martin, 1973). In addition, Kaspers, et al., (1990), studied the distribution of antibody classes in freshly laid eggs $(\mathrm{mg} / \mathrm{ml})$ in chickens. They found that the concentrations of the antibody classes of egg yolk were $8.7 \mathrm{mg} / \mathrm{ml}$ for $\mathrm{IgY}$, and $0.017 \mathrm{mg} / \mathrm{ml}$ for $\lg A$, while the $\operatorname{lgM}$ was not detected, the present results cleared that the egg yolk is the main source for IgY in chickens.

Recently, Ritu, et al., (2016), compared the immunoglobulin $Y(\lg Y)$ level in laying hens of four different breeds of local chickens. They reported that nonsignificant differences in $\lg Y$ concentration were recorded among different laying breeds of chickens. The $\lg Y$ concentration ranged from 3.35 to $5.83,2.30$ to 2.60 and 1.30 to $1.70 \mathrm{mg} / \mathrm{ml}$ in hens, egg yolk and chicks, respectively. In addition, there were significant differences among genetic lines or breeds. For example, the IgY concentrations reported were $2.2 \mathrm{mg} / \mathrm{ml}$ in Single Comb White Leghorn, $2.0 \pm 0.5$ $\mathrm{mg} / \mathrm{ml}$ in line SLU-1329, and $1.7 \mathrm{mg} / \mathrm{ml}$ in Rhode Island Red (Carlander, 2002).

Also, Hamal et al., (2006) studied the concentration of IgY in the dam's plasma, and egg yolk in two meat lines of chickens. They found that the $\lg Y$ concentration in dams plasma was 3.26 $\mathrm{mg} / \mathrm{ml}$, while it was $1.15 \mathrm{mg} / \mathrm{ml}$ in egg yolk with IgY in egg yolk total $22.5(\mathrm{mg})$ in the first line. The corresponding concentrations in the second meat line were $6.02 \mathrm{mg} / \mathrm{ml}$ in dams and $2.26 \mathrm{mg} / \mathrm{ml}$ in egg yolk with total egg yolk of IgY $\mathbf{4 3 . 9}$ (mg).

\section{Effects of maternally transferred antibodies to offspring on some productive traits in chickens:}


Maternal antibody (IgY) transferred from dams to their offspring had direct or indirect effects on some productive traits in chickens such as:

\subsection{Fertility and hatchability:}

In chicken strains, the main interest has been focused on the percentages of fertility and hatchability in relation to the immune response system as a useful system that can combat diseases with an integrated physiological response (Kelly et al., 2000).

Also, Abd El-Rahman, Amira (2006) reported that the high immune response line had higher percentages of fertility and hatchability than the control and low immune response lines in both Norfa and WL strains of chickens. In addition, the statistical differences between strains of chickens in both fertility and hatchability were highly ( $p \leq 0.01$ ) significant. She found that Norfa strain had higher fertility percentage than WL strain, with an fertility average of $92.16 \%$ and $74.15 \%$, whereas the hatchability averages were $86.25 \%$ and $68.88 \%$, respectively.

\subsection{Livability and pathogen resistance:}

The primary short-term benefit of maternal antibody (IgY) transferred from dams to their neonates during the vulnerable period when their own immune system has not yet matured. This has been taken advantage where the laying hens are vaccinated to provide passive immunity to their chicks (Goddard et al., 1994). Both the diversity and the amount of maternal antibody being transferred to the neonate are of importance for the passive protection of the young chicks (Nicoara et al., 1999).

The time period when maternal antibody $(\lg Y)$ retained in the circulation of the neonate is dependent on the initial level provided which is restricted to a period before and shortly after birth. The age at which the neonate starts to produce antibodies on its own system differs markedly between species (Grindstaff et al., 2003). In some birds, increases in the levels of antibodies have been found in 10-14 days post-hatch (Gasparini et al., 2006).

However, maternally transferred antibodies may constitute an important addition to the ability of neonates to take care of pathogens in order to have good livability and low mortality (Gridstaff et al., 2006). Also, Gebriel (1991a) studied the association between the VI-locus controlling livability and the immune response region (IR) in chickens. He found that the VI-locus closely linked to IR-region of the major histocompatibility (MHC) in Fayoumi chickens.

\section{MATERIALS AND METHODS}

The present study was carried out at the Department of Poultry and fish Production, Faculty of Agriculture, Shibin El-Kom, Menoufia University and Poultry Research Station at Gimmizah, Institute of Animal Production and Agricultural Research Center, Ministry of Agriculture. The experiment was extended from Feb. 2016 to Sept. 2017, in order to determine the concentration of the maternal antibody ( $\lg Y)$, as a genetic marker to improve some productive traits in two local strains of chickens.

\section{Chicken stock :}

Two local strains of chickens were used in the present study in the Poultry Research Station at Gimmizah, Institute of Animal Production and Agricultural Research Center, Ministry of Agriculture. The strains of chickens used in the present study were:

\subsection{Silver Montazah strain:}

Silver Montazah strain is a synthetic local strain of chickens, which developed at the Ministry of Agriculture, Montazah Poultry Research Station. The formation 
of Silver Montozah strain started in early 1970 (Mahmoud et al., 1974). The scheme of formation of Silver Montazah strain including two way cross between RIRX Dokki4, random mating and selection programs to select and develop the Silver Montazah strain as egg production strain. The plumage color is colonal white. The ear lobes color is red.

\subsection{Sinai (Bedwin fowl):}

Sinai chickens were originally obtained from the desert areas of North and West Sinai Governorates. The Sinai breed probably is originated from the natural cross between some foreign breeds with the local chickens reared in Sinai Governorate since War 1945.

\section{Experimental Design:}

At 18 weeks of age 96 pullets from two local strains, Silver Montazah (SM) and Sinai chickens were taken at random to be used in the present experiment. The pullets were housed individually in wire individual cages in the Poultry Research Station at Gimmizah. Pullets were hatched on the same day. They were reared under the same management practices, and they were immunized using the same vaccination protocols. Eggs were collected and recoded individually for each hen.

At sexual maturity, 4 hens were assigned at random for each sire which formed 12 families of each strain of chickens for reproducing the next generation. Each family contained one sire and 4 hens in both strains.

At 33 weeks of age, 42 eggs were taken at random as one egg from each hen from 21 hens of each strain, which represented 7 families of each strain. Fresh collected eggs were used to determine the concentration of yolk IgY, which transferred from the dam to egg yolk. At the same time, chick blood samples were taken from 80 chicks representing 80 dams (40 dams of each strain) at $4^{\text {th }}$ day of hatch for determination of $\lg Y$ concentration in chicks blood serum. At the same time, 80 blood samples were collected at 34 weeks of age from 40 hens of each strain of chickens which used for determination of $\lg Y$ concentration in hens blood serum.

To study the effect of IgY concentration on some economic traits, dams and chickens were divided into 3 lines on the bases of the $\lg Y$ concentration blood serum $(\mathrm{mg} / \mathrm{ml})$ of each hen as the following:

\subsection{High antibody (IgY) line (HL):}

Hens of each strain reached IgY concentration more than $\overline{\mathrm{X}} \pm S . E$ were selected and considered as the parents of $\mathrm{HL}$ to produce the offspring of the next generation.

\subsection{Low antibody (IgY) line (LL):}

Hens of each strain had IgY concentration lower than $\bar{x} \pm S . E$ were selected and considered as the parents of LL to produce the offspring of the next generation.

\subsection{Control line $(C L)$ :}

Hens of $C L$ were taken at random to form the control line of each strain to produce the offspring of the $C L$ in the next generation. The unselected individuals were culled.

\section{Mating system and reproduction:}

The artificial insemination was used as a mating system for reproducing the next generation. Each family contains one sire and 4 dams. Dams were assigned at random to each sire for reproducing the next generation. Fertile eggs were collected two times a day and numbered according to their dams. Cracked, dirty, and misshapen eggs were removed. Then, fertile eggs were stored in egg storage room at $15-17{ }^{\circ} \mathrm{C}$ for 7 days, with $70 \%$ of relative humidity. 
For hatching, all eggs were moved to the incubation room and left for at lest 12 hours at room temperature. Then, all eggs were set with wide end up in the setting trays according to their dams and incubated in a forced draft incubator at $99.5^{\circ} \mathrm{F}\left(37.5^{\circ} \mathrm{C}\right)$ with a relative humidity of $65 \%$. Eggs were turned every two hours from the $2^{\text {nd }}$ to $18^{\text {th }}$ day of incubation. All fertile eggs were transferred to a separate hatcher in pedigree baskets according to their dams at $98.5{ }^{\circ} \mathrm{F}\left(36.9{ }^{\circ} \mathrm{C}\right)$ and $75 \%$ relative humidity.

\section{Experimental stock management:}

At hatching day, all chicks were removed from the hatcher, wing banded according to their dams for identification. All chicks were brooded in floor brooder with wood shaving litter. The starting brooder temperature was $34{ }^{\circ} \mathrm{C}$ during the first week, then the brooder temperature was decreased gradually from $2-3^{\circ} \mathrm{C}$ every week to reach $20-22^{\circ} \mathrm{C}$ at almost 42 days of age. The chicks were moved to rearing house at eight weeks of age.

All chicks were exposed to continuous artificial light for 24 hours during the first week of age, then; the artificial light was decreased gradually to reach the natural day light by about 8 weeks of age. All chickens were received only natural day light from 9 to 17 weeks of age. At 18 weeks of age, pullets were moved to individual cages in haying house, where they were kept until 42 weeks of age under 16 house light a day.

All chicks were fed ad libitum during brooding, rearing and growing periods on a diet containing $19.0 \%, 17.0 \%$ and $15.0 \%$ crude protein, and 2860,2850 and $2850 \mathrm{Kcal} \mathrm{ME} / \mathrm{Kg}$ diet, respectively. At 17 weeks of age (before sexual maturity), pullets were fed on a diet containing $17.0 \%$ crude protein and $2850 \mathrm{Kcal} \mathrm{ME} / \mathrm{Kg}$ died. At $\mathbf{5 . 0 \%}$ egg production, hens were fed on diet containing $16 \%$ crude protein and $2750 \mathrm{Kcal} \mathrm{ME} / \mathrm{Kg}$ diet until 42 weeks of age. Then, hens were fed on diet containing $15 \%$ crude protein and 2750 $\mathrm{Kcal} \mathrm{ME} / \mathrm{Kg}$ a diet to the end of productive year. All chicks were vaccinated against diseases and were treated similarly throughout the experimental period.

\section{Collection of hen blood samples:}

At 34 weeks of age, $2 \mathrm{ml}$ blood sample was collected in dry tube via the wing vein and one fresh laid egg from each hen were collected on week before bleeding for IgY determinations. The blood samples were centrifuged at $\mathbf{3 . 0 0 0}$ $\mathrm{rpm}$ for $10 \mathrm{~min}$ at $4{ }^{\circ} \mathrm{C}$. The liquid that remained after blood had clotted was collected, placed in disposable tubes and frozen for subsequent laboratory analysis (Siegel and Gross, 1980).

\subsection{Collection of chick blood samples:}

The chicks were bled via the jugular vein at $4^{\text {th }}$ day of hatch using a $0.5 \mathrm{ml}$ heparinized insulin syringe with a 28gauge needle. Plasma samples were collected and stored at $-20^{\circ} \mathrm{C}$ until analysis (Carlander, 2002).

\section{Extraction of egg yolk IgY:}

In recent years, Polsons PEG (Polyethylene glycodal) precipitation method has become the most commonly used and most effective procedure (Polson, 1990). This method is used for extraction of egg yolk IgY. the volume of egg yolk (ml) was recorded during the extraction method to be used for calculating the $\lg Y$ concentration in each egg yolk using the following formula:

IgY concentration in whole egg yolk (mg/egg):

$=$ egg yolk volume $x \quad \lg Y$ concentration in yolk 
The levels of the total $\lg Y$ in the dams blood serum, egg yolk and chicks blood serum were determined in Lab Top in Zagazig City, Sharkia Governorate, using AMS Sat 450 system which imported from England appropriate kits.

\section{Studied traits:}

8.1. The $\lg Y$ concentrations in blood samples and egg yolk:

The concentration of $\lg Y$ were determined in both blood samples of hen at 34 weeks of age and chicks at $4^{\text {th }}$ day of hatch as $\mathrm{mg} / \mathrm{ml}$. Also, the IgY was determined in fresh egg yolk as $\mathrm{mg} / \mathrm{ml}$.

\subsection{Fertility and hatchability percentages:}

Fertility and hatchability were determined for each hen of both strains of chickens. The percentage was calculated for each :

Whereas, hatchability percentage was calculated:

\subsection{Livability percentage:}

The livability percentage of hatched chicks was determined as direct effects of transferred $\mathrm{IgY}$ from dam to its hatched chicks during the first 4 weeks after hatch. The livability percentage was calculated..

\section{Statistical analysis:}

Least square means and their standard errors $(\overline{\mathrm{X}} \pm S . E)$ for each studied trait were calculated for each line within each its strain. Data obtained were statistically analyzed using SPSS (2004). Probability values $\leq 5 \%$ were considered for significance. All percentages data were converted to the corresponding arcsine prior statistical analysis as given by SAS (1988). Duncans multiple range test was used for the multiple comparisons of means (Duncan, 1955).

The statistical model used in the present study was as follows:

$Y_{i j k}=U+S_{i}+L_{j}+(S \times L)_{i j}+e_{i j k}$
Where :

$Y_{i j k}=$ The $I^{\text {th }}$ observation of the individual over all means.

$U=$ The common mean .

$S_{i}=$ The fixed effect of $i^{\text {th }}$ strains.

$\mathrm{L}_{\mathrm{i}}=$ The fixed effect of $\mathrm{j}^{\text {th }}$ lines.

$(S \times L)_{i j}=$ The fixed effect of interaction between strains and lines.

$\mathrm{e}_{\mathrm{ijk}}=$ experimental error .

\section{RESULTS AND DISCUSSION}

1. The concentrations of IgY antibody in blood serum and egg yolk:

1.1. Effects of chicken strains on IgY antibody concentration:

The effects of chicken strains on IgY antibody concentration $(\bar{X} \pm S . E)$ in hens blood serum, egg yolk and chicks blood serum $(\mathrm{mg} / \mathrm{ml})$ in two local strains of chickens (Silver Montazah and Sinai) are given in Table (1). The average of $\lg Y$ concentration in both silver Moniazah and Sinai strains $(\bar{x} \pm$ SE) were $4.22 \pm$ 0.667 and $4.68 \pm 0.739(\mathrm{mg} / \mathrm{ml})$ in breeding hens blood serum, $3.46 \pm 0.421$ and $4.11 \pm 0.671(\mathrm{mg} / \mathrm{ml})$ in egg yolk and $2.66 \pm 0.396$ and $3.09 \pm 0.412$ in newly hatched chicks blood serum, respectively.

It is clear that Sinai strain had significantly $(P \leq 0.05)$ higher $\lg Y$ concentration in hens, egg yolk and chicks than Silver Montazah strain. Also, Sinai strain had highly significantly $(P<$ 0.01 ) higher egg yolk total concentration of $\lg Y(\mathrm{mg})$ per egg than Silver Montazah strain $(48.0 \pm 1.013$ vs $38.41 \pm 0.963$ mglegg), respectively (Table 1 ). Similar results were reported by Carlander (2002). He stated that there were significant differences among genetic lines or breeds. For example, the $\lg Y$ concentrations reported were $2.2 \pm 0.4$ $\mathrm{mg} / \mathrm{ml}$ in Single Comb White Leghorn, 2.0 $\pm 0.5 \mathrm{mg} / \mathrm{ml}$ in line

SLU-1329, and $1.7 \pm 0.5 \mathrm{mg} / \mathrm{ml}$ in Rhode Island Red. 
Table (1): Effect of chicken strains on IgY concentration $(\overline{\times} \pm S . E)$ in hens, egg yolk and chicks in two local strains of chickens.

\begin{tabular}{|l|c|c|c|c|c|}
\hline \multirow{2}{*}{ Traits } & \multicolumn{5}{|c|}{ lgY concentration $(\underline{\underline{x}} \pm S . E)$} \\
\cline { 2 - 6 } & No & S.M. & No & Sinai & $\begin{array}{c}\text { Level of } \\
\text { significantly }\end{array}$ \\
\hline Hen serum $(\mathrm{mg} / \mathrm{ml})$ & 40 & $4.22 \pm 0.667$ & 40 & $4.68 \pm 0.739$ & $0.05^{*}$ \\
\hline Egg yolk $(\mathrm{mg} / \mathrm{ml})$ & 21 & $3.46 \pm 0.421$ & 21 & $4.11 \pm 0.671$ & $0.01^{\star *}$ \\
\hline Egg yolk total $(\mathrm{mg} / \mathrm{ml})$ & -- & $38.41 \pm 0.963$ & -- & $48.0 \pm 1.013$ & $0.01^{\star \star}$ \\
\hline Chick serum $(\mathrm{mg} / \mathrm{ml})$ & 40 & $2.66 \pm 0.396$ & 40 & $3.09 \pm 0.412$ & $0.05^{*}$ \\
\hline
\end{tabular}

S.M. = Silver Montazah strain

* = Significant $(P<0.05)$

** = Highly Significant $(P<0.01)$

Also, it was reported that the average IgY concentration in the dams serum and egg yolk in two meat line chickens was ranged from 3.26 to $6.02 \mathrm{mg} / \mathrm{ml}$ in dams serum and from 1.15 to $2.26 \mathrm{mg} / \mathrm{ml}$ in egg yolk (Hamal et al., 2006). They also, reported that the total egg yolk $\lg Y$ concentration was ranged from 22.5 to $43.9 \mathrm{mg} / \mathrm{egg}$.

On the other hand, Ritu et al., (2016) compared the immunoglobulin $Y$ (IgY) level in laying hens of four different breeds of local chickens. They reported that non-significant differences in $\lg Y$ concentrations were recorded among laying breeds of chickens.

\subsection{Effect of chicken lines on IgY antibody concentration:}

The effects of chicken lines on IgY levels $(\bar{X} \pm S . E)$ in hens of control and selected lines for high (HL) and low (LL) levels of $\lg Y$ in two local strains of chicken (Silver Montazah and Sinai) were given in Table (2). The averages of $\lg Y$ concentrations were $3.74 \pm 1.068,6.15 \pm$ 1.589 and $2.44 \pm 0.676$ in Silver Montazah strain, where the corresponding values in Sinai strain were $4.63 \pm 1.465,6.65 \pm$ 1.665 and $2.47 \pm 0.634$ for control, $\mathrm{HL}$ and LL lines, respectively.

The statistical differences among lines within each strain were highly significant. $(P \leq 0.01)$. The percentages of change of
IgY concentrations from the control line (100\%) were $164.4 \%$ and $65.2 \%$ for high (HL) and low (LL) lines of Silver Montazah strain, respectively. The corresponding values were $143.6 \%$ and $53.3 \%$ for high (HL) and low (LL) lines of Sinai strain, respectively.

The statistical differences between the local strains of chickens (Silver Montazah and Sinai) maybe due to the local disease environment, the nutrient availability, clutch size and pause length. Since, Sinai strain of chickens was originally obtained from the desert areas of North and South Sinai Governorates. So, it was expected to have significantly higher IgY concentrations than Silver Montazah strain.

\section{Effect of IgY antibody transferred} from layers to egg yolk on fertility percentage:

2.1. Effects of chicken strains on fertility percentages:

The fertility percentages of two local strains of chickens, Silver Montazah and Sinai, are given in Table (3). Means of fertility percentages of both strains of chicken were $76.68 \%$ and $76.91 \%$ for Silver Montazah and Sinai strains of chickens, respectively. The statistical differences between both strains of chickens, Silver Montazah and Sinai, were not significant . 
Table (2): Effect of chicken lines $(\overline{\times} \pm S . E)$ on IgY antibody concentration.

\begin{tabular}{|l|c|c|c|}
\hline \multicolumn{1}{|c|}{ Line } & No. & $(\overline{\times} \pm S . E)$ & $\begin{array}{c}\% \text { Change of } \\
\text { control }\end{array}$ \\
\hline \multicolumn{4}{|c|}{ Silver Montazah Strain } \\
\hline Control line & 12 & $3.74 \pm 1.068 \mathrm{~b}$ & 100.0 \\
\hline High IgY line & 15 & $6.15 \pm 1.589 \mathrm{a}$ & 164.4 \\
\hline Low IgY line & 13 & $2.44 \pm 0.676 \mathrm{c}$ & 65.2 \\
\hline \multicolumn{5}{|c|}{ Sinai strain } \\
\hline Control line & 10 & $4.63 \pm 1.465 \mathrm{~b}$ & 100.0 \\
\hline High IgY line & 16 & $6.65 \pm 1.665 \mathrm{a}$ & 143.6 \\
\hline Low IgY line & 14 & $2.47 \pm 0.634 \mathrm{c}$ & 53.3 \\
\hline $\begin{array}{l}\text { * Means having different superscripts in a column with each strain are significantly different (P< } \\
0.05)\end{array}$
\end{tabular}

Table (3): Effects of IgY antibody transferred from layers (2strains) to egg yolk on fertility.

\begin{tabular}{|l|c|c|c|}
\hline Chicken strains & No, of Layers & $\begin{array}{c}\text { Fertility (\%) } \\
\overline{\times} \pm S . E)\end{array}$ & $\begin{array}{c}\text { Level of } \\
\text { significance }\end{array}$ \\
\hline Silver Montazah & 40 & $76.68 \pm 3.42$ & N.S. $^{*}$ \\
\hline Sinai & 40 & $76.91 \pm 3.48$ & \\
\hline
\end{tabular}

N.S. = Not significant

In chicken strains, the main interest has been focused on the percentages of fertility in relation to the immune response system as a useful system that can combat diseases with an integrated physiological response (Kelly et al., 2000).

The present results disagree with the results reported by Abd El-Rahman, Amira (2006). She found that Norfa strain had significantly higher fertility percentages than White Leghorn strain with an fertility percentages average of $\mathbf{9 2 . 1 6} \%$ vs $\mathbf{7 4 . 1 5 \%}$, respectively.

\subsection{Effects of chicken lines on fertility percentage:}

The effects of control and selected lines for high (HL) and low (LL) IgY concentration of two local strains of chickens on fertility percentages are given in Table (4). The results explained that the high IgY antibody had significantly higher percentage of fertility than the control and low IgY antibody lines in both Silver Montazah and Sinai, strains of chickens. The statistical differences among lines were significant $((P \leq 0.05)$. Also, the interaction between $(S \times L)$ was highly significant $(P \leq 0.01)$.

The averages of fertility percentage of both strains of chickens were 76.97 vs $\mathbf{7 7 . 2 1}$ for control lines, $\mathbf{8 5 . 2 9}$ vs $\mathbf{8 8 . 1 9}$ for high lines and 68.38 vs $\mathbf{6 8 . 8 1}$ for low lines of Silver Montazah and Sinai strains of chickens, respectively (Table, 4).

Similar results were reported by Abd El-Rahman, Amira (2006). She found that the high antibody level lines had higher percentage of fertility than the control and low antibody level lines in both Norfa and WL strains of chickens. Also, the statistical differences among lines were highly significant $(P \leq 0.01)$. 
Table (4): Effect of selected line of chickens on fertility percentage.

\begin{tabular}{|c|c|c|c|}
\hline Lines & no. of Layers & $\begin{array}{c}\text { Fertility (\%) } \\
(\overline{\times} \pm S . E)\end{array}$ & $\begin{array}{c}\% \text { change as } \\
\text { control }\end{array}$ \\
\hline \multicolumn{4}{|c|}{ Silver Montazah } \\
\hline Control & 12 & $76.97 \pm 3.49 b$ & 100.00 \\
\hline High line & 15 & $85.29 \pm 4.16 a$ & 110.81 \\
\hline Low line & 13 & $68.38 \pm 3.12 c$ & 88.84 \\
\hline \multicolumn{4}{|c|}{ Sinai } \\
\hline Control & 10 & $77.21 \pm 3.51 b$ & 100.00 \\
\hline High line & 16 & $88.19 \pm 4.21 a$ & 114.22 \\
\hline Low line & 14 & $63.81 \pm 2.97 c$ & 82.64 \\
\hline
\end{tabular}

* Means having different superscripts in a column with each strain are significantly different $(P<$ 0.05)

\section{Effect of the IgY antibody transferred from layers to egg yolk on hatchability percentages:}

3.1. Effects of chicken strains on hatchability percentages:

The average of hatchability percentages of two local strains of chickens, Silver Montazah and Sinai are given in Table (5). The means of hatchability percentages of both local strains of chickens were $72.32 \%$ and $\mathbf{7 7 . 6 0 \%}$ for Silver Montazah and Sinai, respectively. Sinai strain had significantly $(P \leq 0.05)$ higher percentage of hatchability than Silver Montazah of chickens .

The present results agree with the results reported by Abd El-Raman, Amera (2006). She found that Norfa strain had significantly higher percentage of hatchability than White Leghorn strains of chickens. The averages of hatchability were 86.25 vs $68.88 \%$ for Norfa and White Leghorn strains of chicken, respectively. The statistical differences between strains of chickens were highly $(P \leq 0.01)$ significant.

\subsection{Effects of chicken lines on hatchability percentages:}

The effects of control and selected lines for high (HL) and (LL) IgY concentration of two local strains of chickens on hatchability percentages are given in Table (6). The results explained that high $\lg Y$ lines had higher percentages of hatchability than both control and low IgY lines in both local strains of chickens. Means of hatchability percentages were 89.18, 75.11 and $57.07 \%$ for high, control and low likes, of Silver Montazah chickens, respectively. Similar trend was observed in Sinai chickens, the means of hatchability percentages were 91.89, 77.65 and $61.33 \%$ for high, control and low lines of Sinai chickens, respectively. The statistical differences in hatchability percentages among lines were highly significant $(P \leq 0.01)$. Also, the statistical differences of the interaction $(S \times L)$ were highly significant $(P \leq 0.01)$.

The present results were in good agreement with the results obtained by Abd El-Rahman, Amira (2006). She reported that the high $\operatorname{IgY}$ antibody line 
had higher percentages of hatchability than the control and low IgY antibody lines in both Silver Montazah and Sinai strains of chickens. Also, she reported that the statistical differences among lines of both local strain of chickens were highly significant $(P \leq 0.01)$.

4. Effects of IgY antibody transferred from layers to hatched chicks on livability:

\subsection{Effects of chicken strains on} livability percentages:

The effects of two local strains of chickens, Silver Montazah and Sinai on livability percentages are given in Table (7) Means of livability percent of both local strains of chickens, Silver Montazah and Sinai were $75.14 \%$ vs $80.65 \%$, respectively. The statistical differences between strains of chickens were significant $(P \leq 0.05)$.

It was reported that newly hatched chicks started to produce antibodies on its own immune system differs markedly between species (Grindstaff et al., 2003). In some birds, production of antibodies may constitute an important addition to the ability of newly hatched chicks to take care of pathogens in order to have good livability and low mortality (Gridstaff et al., 2006).

\subsection{Effects of chicken lines on livability:}

Effects of control and selected lines for high (HL) and low (LL) IgY levels of two local strains of chickens on livability Table (5): Effects of two local strains of chickens .

\begin{tabular}{|l|c|c|c|}
\hline Chicken strains & No, of Layers & $\begin{array}{c}\text { Hatchability(\%) } \\
\overline{\times} \pm S . E)\end{array}$ & $\begin{array}{c}\text { Level of } \\
\text { significance }\end{array}$ \\
\hline Silver Montazah & 40 & $72.32 \pm 3.11$ & 0.01 * \\
\hline Sinai & 40 & $77.60 \pm 4.14$ & \\
\hline
\end{tabular}

* = significant $(P \leq 0.05)$ percentages are given in Table (8). The results explained that the livability associated with the $\lg Y$ concentration in layers. High IgY lines had higher percentages of livabity. The means of livability percentage were 75.83 vs $\mathbf{8 0 . 9 1 \%}$ for control lines, 87.92 vs $\mathbf{9 3 . 4 9 \%}$ for high lines 65.29 vs $65.79 \%$ for low lines of Silver Montazah and Sinai strains of chickens, respectively.

High IgY lines increased livability percentages by 15.09 to $17.70 \%$, where low IgY lines decreased livability percentages by 16.95 to $21.16 \%$ as compared to control lines of both strains of chickens. The statistical differences among lines were highly significant $(P \leq 0.01)$.

In this respect, the antibody response of the immune system or transferred from layers to newly hatched chicks was genetically resistance to Marek's disease (Briles and Oleson, 1971), tuberculin bacteria (Karakoz et al., 1974). Salmonilla pullorum and Newcastle disease virus (Pevzner, et al., 1981), lymphoid leucosis disease (Gebriel et al., 1979, Nordskog and Gebriel, 1983), Escherichia coli (Peleg, et al., 1985) and livability (Gebriel, 1991b).

In addition, high IgY lines increased the livability (\%) by 15.09 to $17.72 \%$, where, low IgY lines decreased livability (\%) with 16.95 to $21.16 \%$ as compared to control lines of both strains of chickens. But, the statistical differences of the interaction $(S \times L)$ were not significant. 
Table (6): Effects of control and selected lines for high (HL) and low (LL) of IgY concentration of two local strains of chickens on hatchability percentages.

\begin{tabular}{|c|c|c|c|}
\hline Lines & no. of Layers & $\begin{array}{c}\text { Hatchability (\%) } \\
\overline{(\bar{x} \pm S . E})\end{array}$ & Level of significance \\
\hline \multicolumn{4}{|c|}{ Silver Montazah } \\
\hline Control & 12 & $75.11 \pm 3.09 b$ & 100.00 \\
\hline High line & 15 & $89.18 \pm 5.92 a$ & 118.73 \\
\hline Low line & 13 & $57.07 \pm 2.96 c$ & 75.98 \\
\hline \multicolumn{4}{|c|}{ Sinai } \\
\hline Control & 10 & $77.65 \pm 4.15 b$ & 100.00 \\
\hline High line & 16 & $91.89 \pm 6.05 a$ & 118.34 \\
\hline Low line & 14 & $61.33 \pm 3.67 c$ & 78.98 \\
\hline
\end{tabular}

* Means having different superscripts in a column with each strain are significantly different $(P<$ 0.05).

Table (7): Effects of strain of chickens on livability percentages.

\begin{tabular}{|l|c|c|c|}
\hline Chickon strains & $\begin{array}{c}\text { no. of hatched } \\
\text { chicks }\end{array}$ & livability (\%) \pm SE & $\begin{array}{c}\text { Level of } \\
\text { significance }\end{array}$ \\
\hline Silver Montazah & 269 & $75.14 \pm 4.49$ & $0.05 *$ \\
\hline Sinai & 308 & $80.65 \pm 4.48$ & \\
\hline
\end{tabular}

${ }^{*}=$ significant

Table (8): Effects of selected lines of chickens on livability percentage.

\begin{tabular}{|l|c|c|c|}
\hline Lines & $\begin{array}{c}\text { no. of hatched } \\
\text { chicks }\end{array}$ & $\begin{array}{c}\text { Livability (\%) } \\
\overline{\times} \pm S . E)\end{array}$ & $\begin{array}{c}\text { \% Change of } \\
\text { control }\end{array}$ \\
\hline Control & \multicolumn{3}{|c|}{ Silver Montazah } \\
\hline High line & 80 & $75.83 \pm 3.09 \mathrm{~b}$ & 100.00 \\
\hline Low line & 108 & $87.92 \pm 5.92 \mathrm{a}$ & 115.09 \\
\hline & 81 & $65.29 \pm 2.96 \mathrm{c}$ & 83.05 \\
\hline Control & 77 & Sinai & 100.00 \\
\hline High line & 125 & $80.91 \pm 3.30 \mathrm{~b}$ & 117.72 \\
\hline Low line & 106 & $93.49 \pm 2.06 \mathrm{a}$ & 78.84 \\
\hline
\end{tabular}

* Means having different superscripts in a column with each strain are significantly different $(P<$ 0.05) 


\section{REFERENCES}

Abd El-Rahman, Amira (2006). Relationship between immune response to sheep red blood cells and reproductive performance in chicken. M.Sc. Thesis. Faculty of Agriculture, Minufiya University, Egypt.

Biard, C., P.F. Surai and A.P. Moller (2007). Analysis of pre- and post hatching maternal effects mediated by caroten-oids in the blue. Tite. F. Evol. Biol. 20, (326-333).

Blount, I.D., P. Surai, M.L. Trewby and M.W. Kennedy (2002). Carotenoids and egg quality in the lesser blackbacked gull larus fuscus: a supplemental feeding study of maternal effects. Proc. R. Sec. B 269.(29-36).

Briles, W.E. and W.L. Oleson (1971). Differential depletion of $\mathbf{b}$ blood group genotypes under stress of marek's disease. Poultry Sci., 50 (1550-1558).

Carlander, D. (2002). Avian IgY antibody. In vivo and in vitro Ph.D. Thesis: University of Uppsala, Faculty of Mede. (Sweden).

Duncan, D.B. (1955). Multiple Range and Multiple F. Test. Biometrics, 11:1.

Gasparini, J., T. Boulinier, V.A. Gill, D. Gill, S.A. Hatch and A. Roulin (2006). food availability affects the maternal transfer of androgens and antibodies into eggs of acolonial seabird. F. Evol. Biol. 20 (874-880).

Gebriel, G. M. (1991 a). Genatic association between immune response region and viability in chickens. Egyptian J. APP. Sci. 6(3): 268-209.

Gebriel, G.M. (1991 b). Genetic relationship of each of body weight and chickens immune respose with major his to compatibility complex in fayoumi chickens. Egyptian Journal of Applied Sci., 6(4):249-260.

Gebriel, G.M., I.Y. Pevzner and A.W. Nordskog (1979). Linkage between immune reponse to gat and the fate of rsv-induce tumours in chickens. Immunogenetics, 9: 327.

Glezen, P. (2003). Effect of maternal antibodies on the infant immune response. vaccine 21 , 3389-3392.

Goddard, R. D., P.J. Wyeth and W.C. Varney (1994). Vaccination of commercial layer chicks against infectious bursal disease with maternally derived antibodies. Vet. Rec. 135, (273-274).

Grindstaff, J.L., E.D. Brodie and E.D. Ketterson (2003). Immune function across generations: integrating mechanism and evolutionary process in maternal antibody transfer. Proc. $\mathbf{R}$. Socb 270, (2309-2319).

Grindstaff, J., D. Hasselquist, J.A. Nilsson, N. Sandell, H.G. Smith and M. Stjernman (2006). Transgenerational priming of immunity: maternal exposure to a bacterial antigen enhance offspring humoral immunity. Proc. R. SOC. B 273, (2551-2557).

Hamal, K.R., S.C. Burgess, I.Y. Penzner and G.F. Erf. (2006). Maternal antibody transfer from dams to their egg yolks, egg whites, and chicks in meat lines of chickens. Poultry. Sci. 85: (13641372).

Karakoz, I., J. Krejci, K. Hala, B. Blaszczyk, T. Hraba and J. Pekarek (1974). genetic deremination of tuberculin hypersensitivity in chicken inbred lines. Eur. J. Immunol. 4 (545548).

Kaspers, B., I. Schranner and U. Losch (1990). Immunoglobulin IgY in the yolk of chicken eggs. J. Anim. Physiol. A. Anim. Nutr. 63: (30-37).

Kelly, H.R.C., J.M. Bruce, S.A. Eeward, P.R. English and S. Fowler (2000). Limb Injuries, Immune Response and Performance of Early Weaned Pigs in Different Housing System. J. of Animal Sci., 70: (3-83). 
Lemke, H., A. Coutinho and H. Lange (2004). Lamarckian inheritance by somatically acquired maternal IgY phenotypes. Trends Immunol. 25:(180186).

Lestie, G.A. and L.N. Martin (1973). Modulation of immunoglobulin ontogeny in the chicken: effect of purified antibody specific for $M$ chain on $\lg M, \lg Y$ and $\lg A$ production. $J$. Immunol. 110: (959-967).

Mahmoud, T.H., I.F. Sayed and Y.H. Madkour (1974). The "Silver Montazah" Anew Variety of Chickens. Agric. Res. Rev., Cairo, 52:(97-105).

Nicoara, C., K. Zach, D. Trachsel, D. Germann and L. Andmatter (1999). Decay of passively acquired maternal antibodies against measles, mumps and rubella viruses. Clin. Diag. Lab. Immunol. 6 (868-871).

Nordskog, A.W. and G.M. Gebriel (1983). Rous Sarcoma virus induced tumour expression in chickens.Poultry Sci., 62: (752-762).

Peleg, B.A., E.D. Heller and J. Pitcovsky (1985). The Ontogeny of the humoral response to escherichia coli vaccine and to sheep red blood cells in young chicks .Avain Pathol. 14 (471-481).

Penvzner, I.Y., I. Kujdych and A.W. Nordskog (1981). Immune response and disease resistance in chickens. 2. marek's disease and immune response to GAT. Poultry Sci. 60: (927-932).

Polson, A. (1990). Isolation of IgY from the yolks of eggs by a chloroform ploly ethylene procedure. Immunol. Invest., 19(3): (253-258).

Ritu, A., Mahesh Puri Goswami and P. Ravi (2016). Bochner theorem and applications of bicomplex Fourier. stieltjes transform. advanced studies in contemporary Mathematics 26.No.2, pp.(355-369).

Rubolini, D., M. Romano, A. Alquati and N. Saino (2006). Early maternal, genetic and environmental components of antioxidant protection,morphalogy and immunity of yellow-legged gull (larus michahellis) chicks. F. Evol. Biol. (1571- 1584).

SAS (1988). As the foundation for SAS analytics SASISTAT provides state of the art statistical analysis software that empowers you to make new discoveries.

Https://Www.Sas.Com>En-Us>Stat.

Schade, R. and A. Hlinak (1996). Egg yolk antibodies, state of the art and future prospects. altex, 13 (1): 5-9.

Siegel, P.B., W.B. Gross and J.A. Cherry (1980). Correlated responses of chickens to selection for production of antibodies to sheep erythrocyted. Anim.Blood Group Bichem Gen., B. (291-297).

SPSS (2004). PC.Programe. by Spss Inc., North Michigan, US.A.

Sun, S., W. MO, Y. Ji and S. Liu (2001). Preparation and mass spectrometric study of egg yolk antibody (igy) against rabies virus. Rapid Communication of Mass Spectrometry. 15: (708-712). 
تقدير تركيز المناعة الأمية (IgY) كلاليل وراثي لتحسين نسب الخصوية والفقس والحيوية في سلالتين من الاجاج المحلي

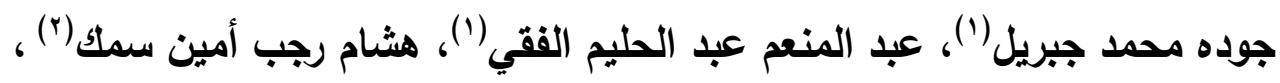

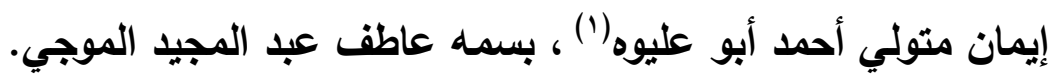

(1) قسم إنتاج الدواجن والأسماك - كلية الززراعة - جامعة المنوفية - شبين الكوم الكمان

(ץ) معهة بحوث الانتاج الحيواني ، مركز البحوث الززاعية

الملخص العربي

أجريت هذه الدراسة بقسم إنتاج الدواجن و الأسماك ، كلية الزراعة بثبين الكوم ، جامعة المنوفية ، وامتدت

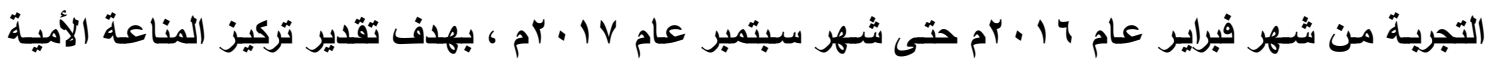
(IgY) وسيناء كليل وراثي لتحسين نسب الخصوية والفقس والحيوية ـ وقد نوقثت النتائج ولخصت في في النقاط النيا التالية

1- حققت سلالة دجاج سيناء تركيز مغنوى عالى للمناعة الأمية (IgY antibody) عن سلالة المنتزه

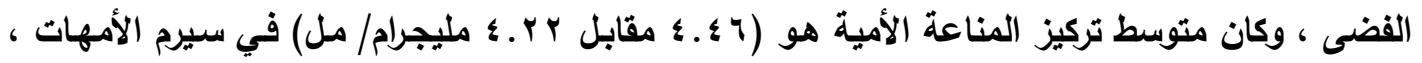

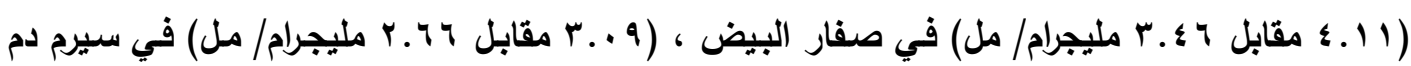

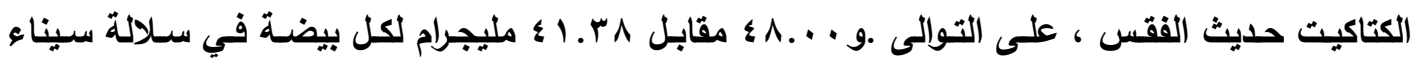

$$
\text { والمنتزه الفضي علي التوالي. }
$$

r- حقق الخط عالى المناعة (HR) أعلا تركيز من المناعة الأمية ، وحقق خط المقارنة (CL) تركيز متوسط،

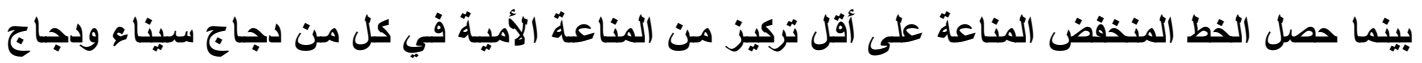

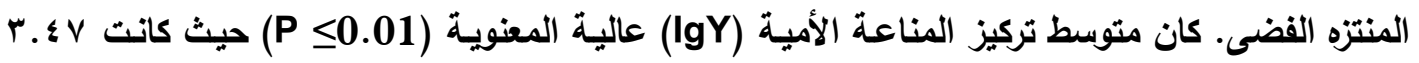

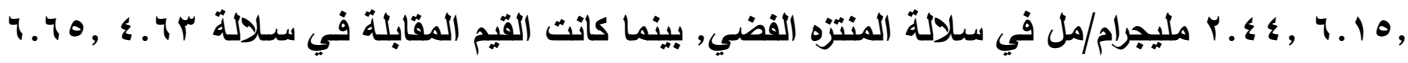

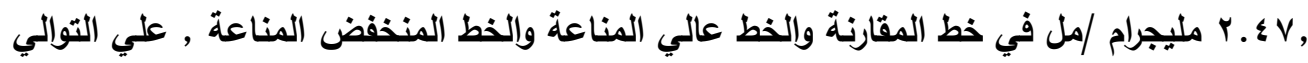

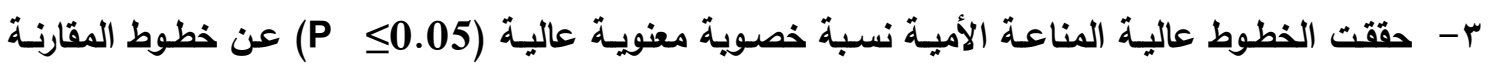

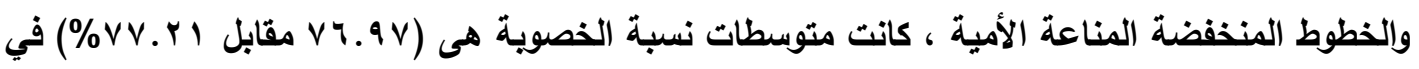

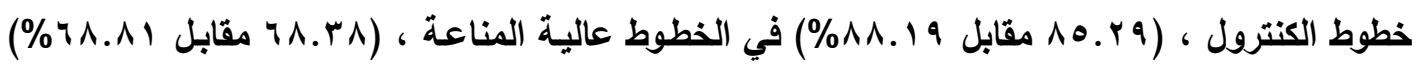

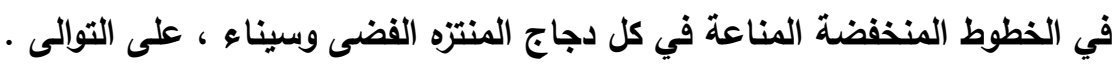

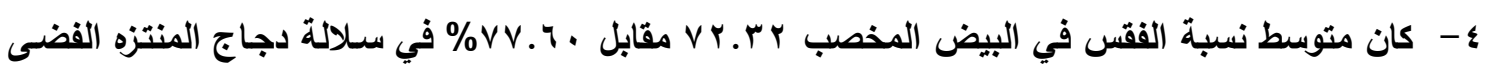

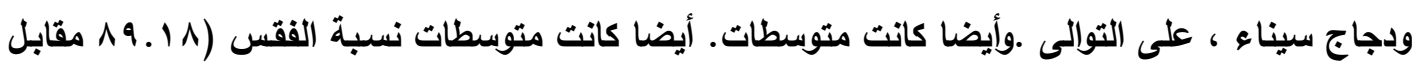




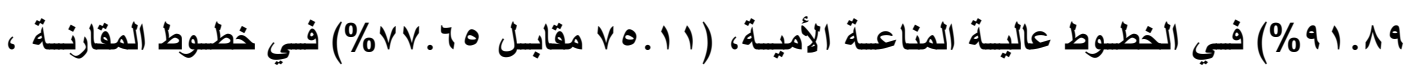
(ov. . V) التوالى

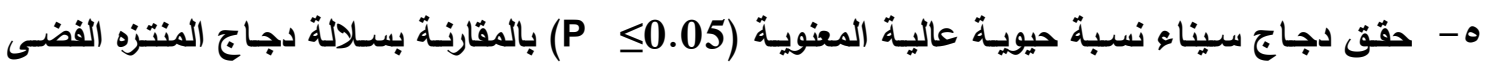

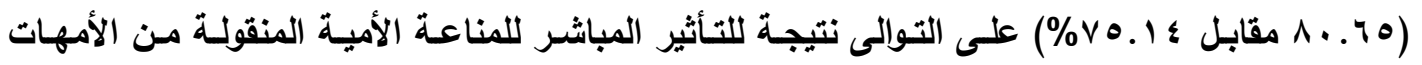
البياضة إلى الكتاكيت حديثة الفقس. צ- حققت الخطوط عالية المناعة الأمية نسبة حيوية عالية معنويا (P S 0.05) . كان متوسط نسبة الحيوية

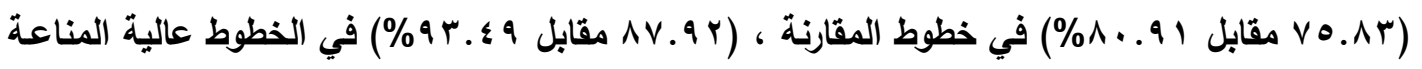

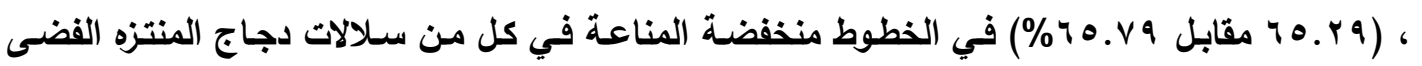
وسيناء ، على التوالى. - هذه النتائج تؤكد إمكانية استخدام تركيزات المناعة الأمية كدليل وراثى لتحسين بعض الصفات الإنتاجية في الاجاج. 
G. M. Gebriel, et al.,

أ.دد/ فاروق حسن عبـــــده كلية الزراعة جامعة المنوفية 